Am. J. Hyg., 24 : 381-406, 1936.

11) Morishita, T. Kobayashi, M. and Nagata,

$\mathrm{Z}:$ On the Hooworm infection circuit traced with isotope $\mathrm{P}^{32}$ marked larvae. Jap. J.
Exp. Med., 23 : 531-536, 1953.

12) 永田二郎：鈎虫の後感染抵抗性に関す万研究, 岐 旱医大紀要，2：355-372，1955.

\title{
STUDIES ON HOOKWORM IMMUNITY (ANCYLOSTOMA GANINUM)
}

\section{1) PRELIMINARY REPORT ON IMMUNITY AGQUIRED BY}

\section{INFECTION WITH LARAE}

Megumi Kono, Toshisada Sawada

Department of Hygiene, School of Medicine, Gunma University

Studies were carried out using mice as experimental hosts to detemine whether immunity can be established against Ancylostoma caninum, and the following results were obtained;

1) The mortality of the mice, infected with the larvae of A. caninum, depended upon the numbers of larvae.

2) Mice infected with 300, 700, and 1,500 larvae orally at the intervals of 6 days and 15 days showed a resistance to challenging infection of 5,000 larvae orally.

3) In mice, immunized with previous infection and remarked no protection to challenging infection, less numbers of larvae were detected from organs of the body than from those of non-immunized control.

\section{鈎虫 の感染と免 疫}

第 2 報 犬鈎虫幼虫マウス経口感染実験に於けるマウス

の感受性と幼虫の感染能について

$$
\begin{gathered}
\text { 沢田 利 貞・河 野 恵 } \\
\text { 群馬大学医学部衛生学教室 }
\end{gathered}
$$

\section{緒}

\section{言}

前報に於てマウス犬鈎虫幼虫を予め少数感染 しておくと後の大量の再感染に耐えて感染死を 免れ又体内よりの分離幼虫数の減少が認められ ることを報告した．今回更に犬鈎虫幼虫を $\mathrm{ddN}$ 系マウス（群大純系動物舎）に経口感染した場 合のマウスの死亡状沅について実験し種々の生 後日数（体重）のマウスの感受性並びに新，旧 培養の幼虫の感染能の相異について $2 \sim 3$ の知 見を得た。

\section{実験材料並びに方法}

種々の生後日数のマウスに一定数の幼虫を感染させ マウスの感受性を，又生後日数一定のマウスに新旧培 養幼虫を経口感染させ幼虫の感染能を夫々幼虫感染に よるマウスの体重変化並びに死亡状況から観察した。 感染に使用した幼虫 $\left(28^{\circ} \mathrm{C} ， 8\right.$ 日培養）並びに幼虫 の感染方法は前報と同様に行い，マウスは群大純系動 物舎より供給された ddN 系雄マウスを用いた。感染 経過中のマウスはオリエンタル固型飼料及び水を以て 飼育し，体重は毎日午前 9 時より9 時30分の間に電気 自動科により測定し，最低 $18^{\circ} \mathrm{G} に$ 保った動物飼育室で 原則として30日間観察した。 


\section{実 験 成 績}

\section{( I )種々の生後日数(体重)のマウスの感受性}

（1）生後 3 週のマウスに 8 日培養の幼虫を経 口感染した場合のマウスの体重変化並び に死亡状況

平均体重 $10.8 \mathrm{~g}$ のマウスを 1 群10匹宛として 幼虫を夫々 4,000 隻， 3,000 隻，2,000隻，1,000 隻及び 500 隻宛経口感染したところ，幼虫 4,000 隻感染群は翌日より体重は減少し始め, 以後体 重は回復することなく12日後マウスは総て死亡 した。幼虫 3,000 隻感染群も同上経過をとって 13日後マウスは総て死亡した。

幼虫 2,000 隻感染群は感染後 2,3 日体重は降 下し 3 日乃至 10 日の間に10匹中 5 匹死亡し，以 後 20 日目及び 24 日目にも夫久 1 匹宛死亡し， 30 日の観察期間中 10 匹中計 7 匹のマウスは, 感染 により死亡した。この間生存マウスは感染後約 1 週間は体重の減少を認めたが, その後は体重 の増加を認めた。

幼虫 1,000 隻感染群では全般的に体重の著明 な減少は認められなかっったが，感染後5日目， 13 日目，19日目及び22日目に夫々 1 匹宛死亡 し，10匹のマウス中計 4 匹のマウスは感染によ

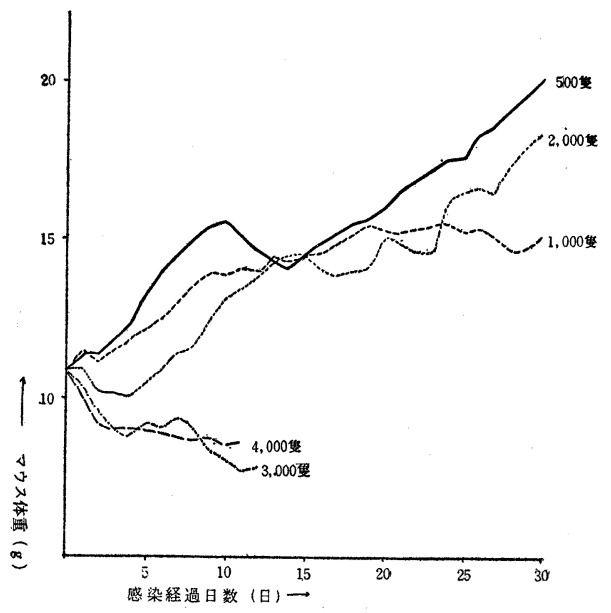

図1 犬鈎虫幼虫経口感染マウスの体重 変化

（1）生後了週の ddN 系雄マウス について 幼虫： $28^{\circ} \mathrm{C} 8$ 日培養
り死亡した。

幼虫 500 隻感染群では感染による体重の減少 は特に認められず10匹共生存した。

30 日間観察の死亡率は幼虫 4,000 隻及び 3,000 隻感染群マウスでは100\%, 幼虫2,000隻感染群 では $80 \%$ ，幼虫1 000 隻感染群では $40 \%$ ，幼虫 500 隻感染群マウスは全部生存した。之を Probit 法により求めるとLD50 は約 1,260 隻で あった（表1，図1）。

（2）生後 5 週のマウスに 8 日培養の幼虫を経 口感染させた場合のマウスの体重変化並 びに死亡状況

平均体重 $22.3 \mathrm{~g}$ の生後 5 週のマウスを 1 群 10 匹 宛とし，幼虫を5,000隻，4,000隻，3,000隻， 2,000 隻, 1,000 隻宛各群のマウスに夫々感染さ せたところ, 幼虫 5,000 隻, 4,000 隻感染群では 総て翌日より著明な体重減少を認め回復するこ となく 5,000 隻感染群では 8 日，4,000染感染群 では11日でマウスは総て死亡した。

幼虫 3,000 隻感染群では 1 匹の夕10日目頃よ り回復に向い生存したが他の 9 匹は感染後 6 日 乃至17日の間に総て死亡した。

幼虫 2,000 隻感染群では 6 匹のマウスは感染 により体重は次符に減少して夫々 8 日目，10日

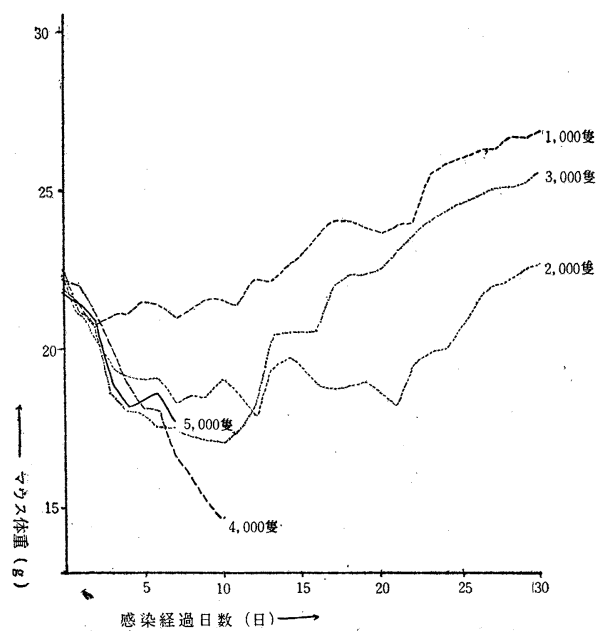

図2 犬鈎虫幼虫経口感染マウスの体重 変化

(2) 生後 5 週の ddN系雄マウスに ว以て 幼虫： $28^{\circ} \mathrm{C}, 8$ 日培養 
表 1 犬鈎虫幼虫経口感染マウスの死亡状況

(1) 生後了週の $\mathrm{ddN}$ 系雄マウスについて 幼虫: $28^{\circ} \mathrm{G} 8$ 日培養

\begin{tabular}{|c|c|c|c|c|c|c|c|}
\hline \multirow{2}{*}{ 感染 } & \multicolumn{2}{|r|}{ 感 } & \multicolumn{4}{|c|}{ 数（日） } & \multirow{2}{*}{$\begin{array}{c}\text { 死亡率 } \\
(\%)\end{array}$} \\
\hline & 5 & 10 & 15 & 20 & 25 & 30 & \\
\hline 500 & 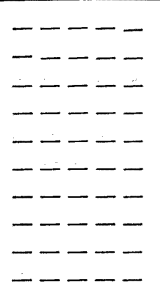 & 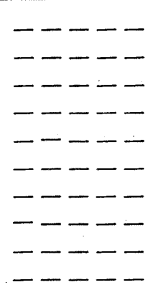 & 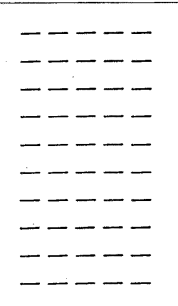 & 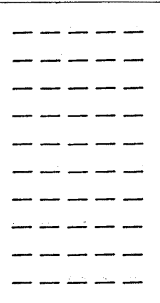 & 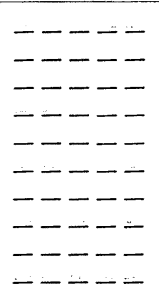 & 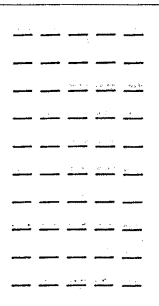 & 0 \\
\hline 1,000 & 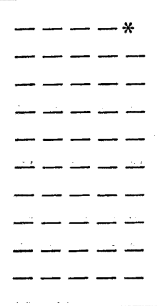 & 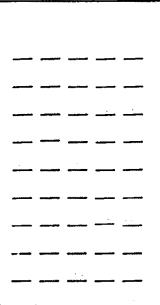 & 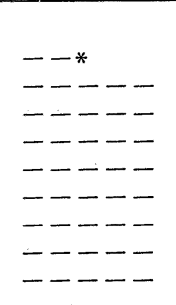 & 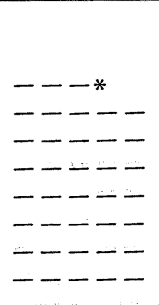 & $\begin{array}{l}-* \\
----- \\
----- \\
----- \\
----- \\
---0-\end{array}$ & $\begin{array}{l}---1- \\
---1 \\
---z= \\
---0 \\
--0-1 \\
---0\end{array}$ & 40 \\
\hline 2,000 & 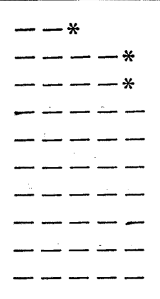 & 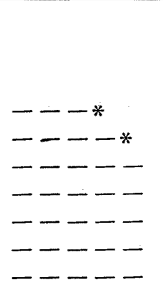 & 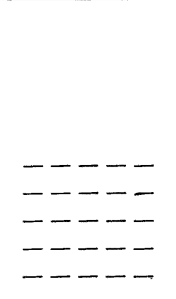 & $\begin{array}{l}----* \\
---\cdots \\
----- \\
----- \\
-----\end{array}$ & $\begin{array}{l}---* \\
----- \\
-\Delta-- \\
-----\end{array}$ & $\begin{array}{l}-\cdots--- \\
----- \\
-----\end{array}$ & 70 \\
\hline
\end{tabular}

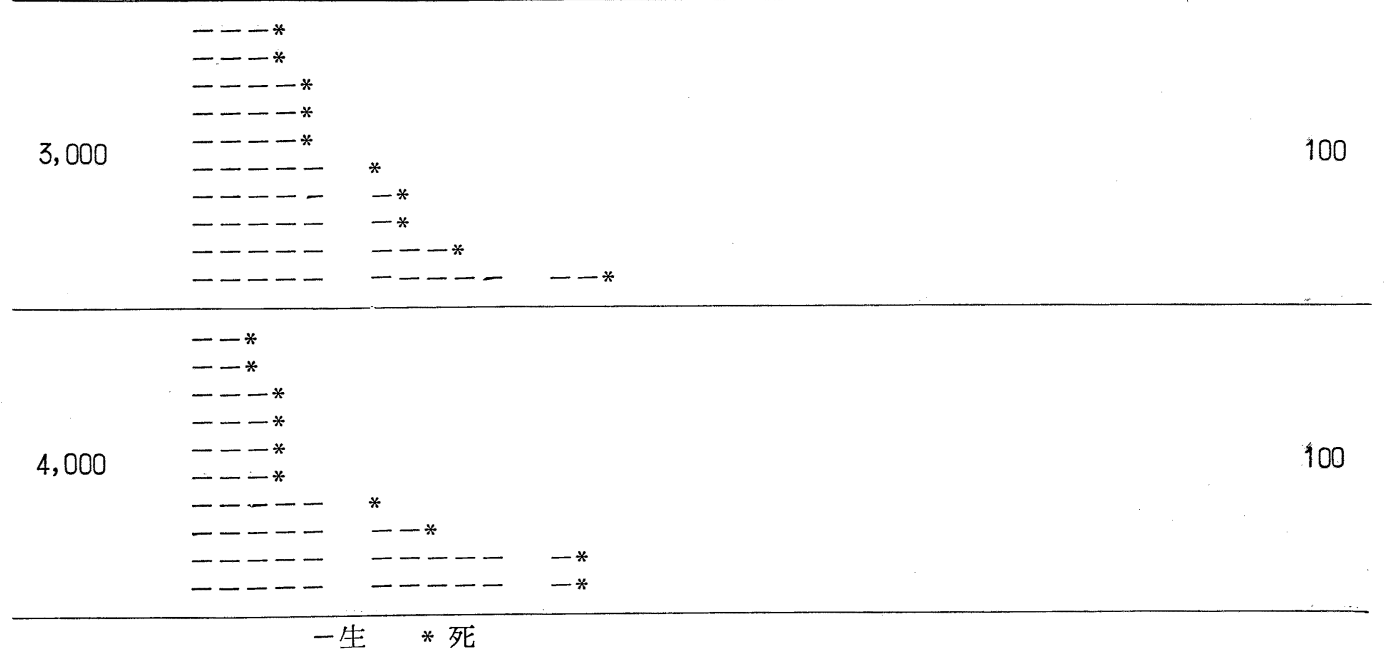

目，13日目，22日目，26日目に死亡した。感染 死を免れた 4 匹のマウスも同様著明な体重の減 少を示したが，約 3 週目頃より次第に体重は増 加し，30日後に漸く感染前の体重に復した。
幼虫 1,000 隻感染群では感染後12日目，17日 目，23日目に1匹宛マウスは死亡した。他の感 染死を免れた 7 匹のマウスは 2,000 隻感染群に 比べ体重の回復は早く感染後約 2 週間ですでに 
感染前の体重に回復した，以上死亡率について 綜合すると幼虫 5,000 隻及び 4,000 隻感染群マウ スの死亡率は $100 \%$ ，幼虫 3,000 隻感染群マウス の死亡率は $90 \%$, 幼虫 2,000 隻感染群マウスの
死亡率は $60 \%$ ，幼虫 1,000 隻感染群マウスの死 亡率は30\%であって Probit 法から LD50を算 出すると約 1,600 隻であ.った（表 2 , 図 2 ).

表 2 犬鈎虫幼虫経口感染、ウスの死亡状況

(2) 生後 5 週の ddN 系雄マウスについて 幼虫: $28^{\circ} \mathbf{C} 8$ 日培養

\begin{tabular}{|c|c|c|c|c|c|c|c|}
\hline \multirow{2}{*}{ 感 虫 数 } & \multicolumn{2}{|c|}{ 感 染 } & 経 & \multicolumn{3}{|c|}{ 数（日） } & \multirow{2}{*}{$\begin{array}{c}\text { 死亡率 } \\
(\%) \\
\end{array}$} \\
\hline & 5 & 10 & 15 & 20 & 25 & 30 & \\
\hline 1,000 & 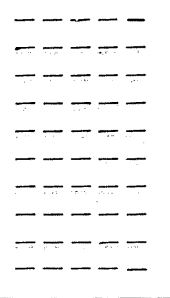 & 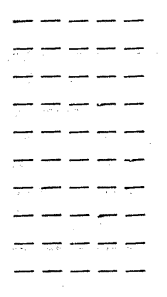 & $\begin{array}{l}-* \\
----- \\
----- \\
----- \\
----- \\
----- \\
----= \\
---1- \\
----- \\
-----\end{array}$ & $\begin{array}{l}-* \\
----- \\
----- \\
----- \\
----- \\
----- \\
----- \\
----- \\
-----\end{array}$ & $\begin{array}{l}--* \\
----- \\
----- \\
----- \\
----- \\
----- \\
----- \\
-----\end{array}$ & $\begin{array}{l}----- \\
----- \\
----- \\
----- \\
----- \\
----- \\
-----\end{array}$ & 30 \\
\hline 2,000 & 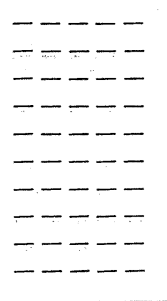 & $\begin{array}{l}--* \\
----* \\
----* \\
----- \\
----- \\
----- \\
---1- \\
----- \\
----- \\
-----\end{array}$ & $\begin{array}{l}--* \\
----- \\
----- \\
----- \\
----- \\
----- \\
-----\end{array}$ & $\begin{array}{l}---\cdots- \\
----- \\
----- \\
----- \\
----- \\
-----\end{array}$ & $\begin{array}{l}-* \\
----- \\
----- \\
----- \\
----- \\
-----\end{array}$ & $\begin{array}{l}* \\
----- \\
----- \\
----- \\
-----\end{array}$ & 60 \\
\hline 3,000 & 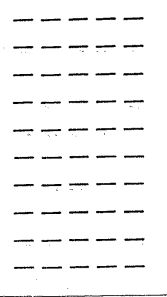 & 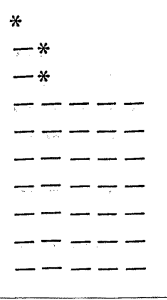 & $\begin{array}{l}* \\
-* \\
---* \\
---* \\
----- \\
-----\end{array}$ & $-*$ & $-\ldots--$ & $-\ldots-$ & 90 \\
\hline 4,000 & $\begin{array}{l}----* \\
----* \\
----- \\
----- \\
----- \\
----- \\
----- \\
---1 \\
----- \\
-----\end{array}$ & $\begin{array}{l}* \\
-* \\
-* \\
---* \\
---* \\
----* \\
----- \\
-----\end{array}$ & $\begin{array}{l}* \\
*\end{array}$ & & & & 100 \\
\hline 5,000 & $\begin{array}{l}--* \\
---* \\
----* \\
----* \\
----* \\
----* \\
----* \\
----- \\
----- \\
-----\end{array}$ & $\begin{array}{l}* \\
-* \\
--*\end{array}$ & & & & & 100 \\
\hline
\end{tabular}


（3）生後 8 週のマウスに 8 日唔養の幼虫を経 口感染させた場合のマウスの体重変化並 びに死亡状況

平均体重 $25.2 \mathrm{~g}$ の生後 8 週のマウスを1群10匹 とし, 幼虫 5,000隻, 4,000隻, 3,000隻, 2,000 隻及び 1,000 隻を夫々各群マウスに感染させた ところ翌日から総てのマウスに体重の減少が著 明に認められた。その中・部のマウスは回復し たがその他のマウスの体重の減少は回復しない で死亡した。

即ち幼虫 5,000 隻感染群マウスでは感染後 3 日 目から 8 日目迄に5匹，14日目に1匹，23日目 に2 匹夫々死亡した。生存した 2 匹のマウスは 約 3 週後から体重は漸次増加 30 日間では未だ感 染前の体重に迄回復しなか・った。

幼虫 4,000 隻感染群マウスの体重変化は殆ど 㓜虫 5,000 隻感染群と同様の増減を示し, 途中 3 日目に 1 匹，7日目，17日目に各 2 匹，27日 目に 1 匹のマウスが死亡した。

幼虫 3,000 隻感染群マウスでは体重の回復は 約10日後より認められたが尚30日後では未だ感 染前の体重に迄 回復しなかっった。この間 6 日 目，14日目，22日目，27日目に夫々1匹のマウ

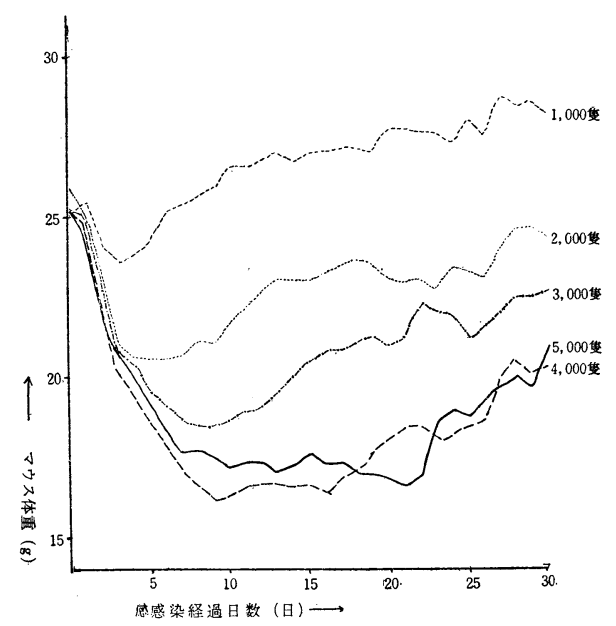

図3 犬鈎虫幼虫経口感染マウスの体重 変化

（3）生後 8 週のddN系雄マウスに ग以

幼虫: $28^{\circ} \mathrm{C} 8$ 日培養
スが死亡した。

幻虫 2,000 隻感染群マウスでは体重の回復は 速かで 1 週後には増加の傾向が認められたが, 途中 24 日目 2 匹，26日目に1 匹のマウスが死亡 した.

幼虫 1,000 隻感染群マウスでは感染により低 下した体重は約 6 日ですでに感染前の体重に回 復し以後増加を続けマウスは総て生存した。以 上死亡率から見ると奻虫 5,000 隻感染群又ウス の死亡率は $80 \%$, 幼虫 4,000 隻感染群マウスの 死亡率は $60 \%$, 幼虫 3,000 隻感染群マウスの死 亡率は $40 \%$, 幼虫 2,000 隻感染群マウスの死亡 率は $30 \%$, 幼虫 1,000 隻感染群マウスの死亡率 は $0 \% て ゙ L D 50 は$ 約 3,200 隻であっった（表 3 , 図 3 )

（4）生後日数の異るマウスに幼虫 4,000 隻感 染させた場合のマウスの死亡状況

同時に培養して得た幼虫を生後日数の異るマ ウス（1 群各10匹）に 4,000 隻宛感染させたと ころ，3 週マウス（平均体重 $(10.8 \mathrm{~g}$ ), 4 週マ ウス群 (平均体重 $16.0 \mathrm{~g}$ ) の死亡摔は $100 \%, 5$ 週マウス群(平均体重21.2g) の死亡率は $70 \%$, 6 週マウス群 (平均体重22.9g) の死亡率は 90 $\%, 7$ 週 マウス群 (平均体重21.3g) の死亡率 は90\%，8週マウス群（平均体重25.4g）の死 亡率は $50 \% ， 9$ 週マウス群（平均体重28.3g） 及び10週マウス群（平均体重27.8g） の死亡率 は各 40\%，16週マウス群（平均体重33.3g） の死亡率は $0 \%$ であっった（表 4 ）。

マウスの生後日数之感染による死亡率，マウ スの体重と感染による死亡率は必ずしも一致し ていないこの関係を知るためには生後日数は同 じで体重の異ったマウスについて及び体重は同 じであるが生後日数の異るマウスについて実験 を行わなくてはならないので本実験の結果では 結論を出すことは出来ないが，本実験の結果に よってマウスの体重及び感染幼虫（8日培養） 数とマウスとの死亡摔 (30日間観察) の関係に ついてまとめると同一体重のマウスでは感染幼 虫数の多い程死亡率は高く, 感染㓜虫数が同じ 
表 3 犬鈎虫幼虫経口感染、ウ 万の死亡状況

(3) 生後 8 週の ddN 系雄マウスについて 幼虫: $28^{\circ} \mathrm{C} 8$ 日培養

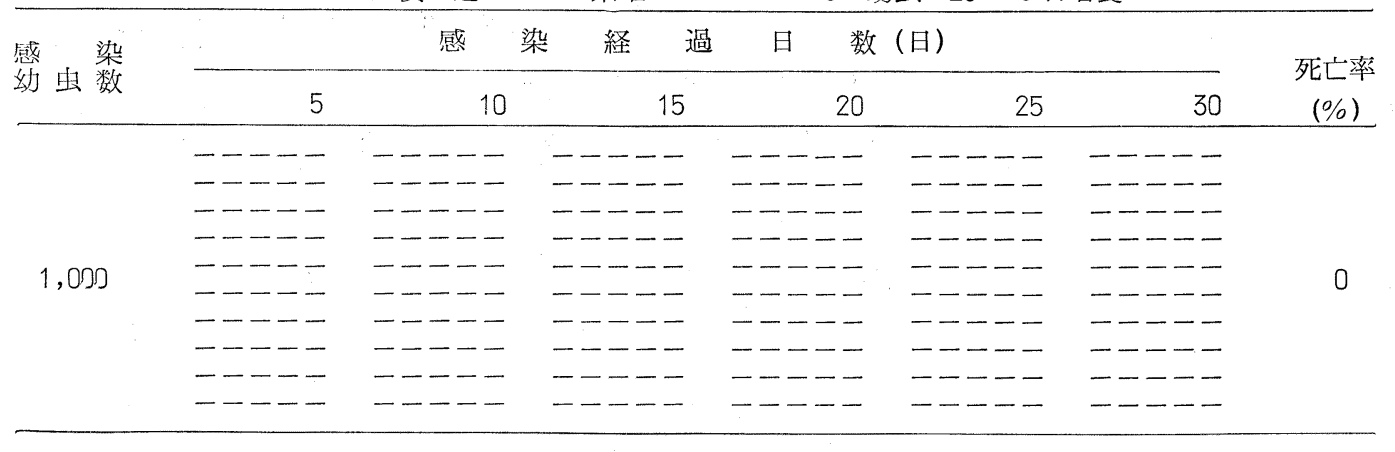

\begin{tabular}{|c|c|c|c|c|c|c|c|}
\hline 2,000 & $\begin{array}{l}--\cdots-- \\
----- \\
----- \\
----- \\
----- \\
----- \\
----- \\
----- \\
-----\end{array}$ & $\begin{array}{l}----- \\
----- \\
----- \\
----- \\
----- \\
----- \\
----- \\
----- \\
-----\end{array}$ & $\begin{array}{l}----- \\
----- \\
----- \\
----- \\
----- \\
----- \\
----\cdots \\
----- \\
-----\end{array}$ & $\begin{array}{l}----- \\
----- \\
----- \\
----- \\
----- \\
----- \\
----- \\
----- \\
-----\end{array}$ & $\begin{array}{l}---* \\
---* \\
----- \\
----- \\
----- \\
----- \\
----- \\
----- \\
-----\end{array}$ & $\begin{array}{l}* \\
----- \\
----- \\
----- \\
----- \\
----- \\
-----\end{array}$ & 30 \\
\hline 3,000 & 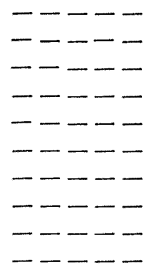 & $\begin{array}{l}* \\
----- \\
----- \\
----- \\
----- \\
----- \\
----- \\
----- \\
----- \\
-----\end{array}$ & $\begin{array}{l}---* \\
----- \\
----- \\
----- \\
----- \\
----- \\
----- \\
----- \\
-----\end{array}$ & $\begin{array}{l}----- \\
----- \\
----- \\
----- \\
----- \\
----- \\
----- \\
-----\end{array}$ & $\begin{array}{l}\text {-* } \\
----- \\
----- \\
----- \\
----- \\
----- \\
----- \\
-----\end{array}$ & $\begin{array}{l}-* \\
----- \\
----- \\
----- \\
----- \\
----- \\
-----\end{array}$ & 40 \\
\hline
\end{tabular}

\begin{tabular}{|c|c|c|c|c|c|c|c|}
\hline 4,000 & $\begin{array}{l}--* \\
----- \\
----- \\
----- \\
----- \\
----- \\
----- \\
----- \\
----- \\
-----\end{array}$ & $\begin{array}{c}* \\
* \\
----- \\
----- \\
----- \\
----- \\
----- \\
----- \\
-----\end{array}$ & $\begin{array}{l}----- \\
----- \\
----- \\
----- \\
----- \\
----- \\
-----\end{array}$ & $\begin{array}{l}-* \\
-* \\
----- \\
----- \\
----- \\
----- \\
-----\end{array}$ & $\begin{array}{l}----- \\
----- \\
----- \\
----- \\
-----\end{array}$ & $\begin{array}{l}-* \\
----- \\
----- \\
----- \\
-----\end{array}$ & 60 \\
\hline 5,000 & $\begin{array}{l}--* \\
---* \\
----- \\
----- \\
---- \\
----- \\
---- \\
---- \\
---- \\
----\end{array}$ & $\begin{array}{l}* \\
-* \\
--* \\
----- \\
----- \\
----- \\
-----\end{array}$ & $\begin{array}{l} \\
---* \\
---- \\
----- \\
----- \\
-----\end{array}$ & $\begin{array}{l}----- \\
----- \\
----- \\
-----\end{array}$ & $\begin{array}{l} \\
--* \\
--* \\
----- \\
-----\end{array}$ & $\begin{array}{l}---- \\
-----\end{array}$ & 80 \\
\hline
\end{tabular}

場合は幼若な（体重が少い）マウス程死亡率が 高いことがわかった（図 4).

\section{（II ) 新，旧唔養幼虫の感染能}

幼虫を少量の水を入れたシャレー内に $28^{\circ} \mathrm{C}$
で 1 週間毎に新鮮な水と交換しながら保存し, 感染に使用する前日に瓦で再分離を行い邈出し て来た活潑な幻虫を使用した。又マウスは生後 3 週のddN系雄を使用した。 
表 4 犬鈎虫幼虫経口感染マウスの死亡状況

（4） 4,000隻の幼虫を各週令マウスに感染した場合

マウス: ddN 系雄 幼虫: $28^{\circ} \mathrm{C}, 8$ 日培養

\begin{tabular}{|c|c|c|c|c|c|c|c|}
\hline \multirow{2}{*}{$\begin{array}{c}\text { マウ ス } \\
\text { 生後 令 } \\
\text { (週) }\end{array}$} & & 感 & 経 & 数 & （日） & & \\
\hline & 5 & 10 & 15 & 20 & 25 & 30 & $(\%)$ \\
\hline 16 & $\begin{array}{l}----- \\
----- \\
----- \\
----- \\
----- \\
----- \\
----- \\
----- \\
-----\end{array}$ & $\begin{array}{l}----- \\
----- \\
----- \\
----- \\
----- \\
----- \\
----- \\
----- \\
-----\end{array}$ & $\begin{array}{l}----- \\
----- \\
----- \\
----- \\
----- \\
----- \\
----- \\
----- \\
-----\end{array}$ & $\begin{array}{l}----- \\
----- \\
----- \\
----- \\
----- \\
----- \\
----- \\
----- \\
-----\end{array}$ & $\begin{array}{l}----- \\
----- \\
----- \\
----- \\
----- \\
----- \\
----- \\
----- \\
-----\end{array}$ & $\begin{array}{l}----- \\
----- \\
----- \\
----- \\
----- \\
----- \\
----- \\
----- \\
-----\end{array}$ & 0 \\
\hline 10 & $\begin{array}{l}---* \\
----- \\
----- \\
----- \\
----- \\
----- \\
----- \\
----- \\
-----\end{array}$ & $\begin{array}{l}---* \\
----- \\
----- \\
----- \\
----- \\
----- \\
----- \\
-----\end{array}$ & $\begin{array}{l}--* \\
----- \\
----- \\
----- \\
----- \\
----- \\
-----\end{array}$ & $\begin{array}{l}----- \\
----- \\
----- \\
----- \\
----- \\
-----\end{array}$ & $\begin{array}{l}----* \\
----- \\
----- \\
----- \\
----- \\
-----\end{array}$ & $\begin{array}{l}----- \\
----- \\
----- \\
----- \\
-----\end{array}$ & 40 \\
\hline 9 & $\begin{array}{l}--* \\
----- \\
----- \\
----- \\
----- \\
----- \\
----- \\
----- \\
-----\end{array}$ & $\begin{array}{l}-* \\
--* \\
----- \\
----- \\
----- \\
----- \\
----- \\
-----\end{array}$ & $\begin{array}{l}----- \\
----- \\
----- \\
----- \\
----- \\
-----\end{array}$ & $\begin{array}{l}* \\
----- \\
----- \\
----- \\
----- \\
-----\end{array}$ & $\begin{array}{l}----- \\
----- \\
----- \\
----- \\
-----\end{array}$ & $\begin{array}{l}----- \\
----- \\
----- \\
----- \\
-----\end{array}$ & 40 \\
\hline 8 & $\begin{array}{l}---{ }^{*} \\
----- \\
----- \\
----- \\
----- \\
----- \\
----- \\
----- \\
----- \\
-----\end{array}$ & $\begin{array}{l}----* \\
----- \\
----- \\
----- \\
----- \\
----- \\
----- \\
----- \\
-----\end{array}$ & $\begin{array}{l}* \\
-* \\
--* \\
----- \\
----- \\
----- \\
----- \\
-----\end{array}$ & $\begin{array}{l}----- \\
----- \\
----- \\
----- \\
-----\end{array}$ & $\begin{array}{l}----- \\
----- \\
----- \\
----- \\
-----\end{array}$ & $\begin{array}{l}----- \\
----- \\
----- \\
----- \\
-----\end{array}$ & 50 \\
\hline 7 & $\begin{array}{l}----- \\
----- \\
----- \\
----- \\
----- \\
----- \\
----- \\
----- \\
----- \\
-----\end{array}$ & $\begin{array}{l}* \\
-* \\
-* \\
---* \\
----- \\
----- \\
----- \\
----- \\
----- \\
-----\end{array}$ & $\begin{array}{l}* \\
-* \\
--* \\
----* \\
---- \\
----\end{array}$ & $-*$ & $-\cdots-\cdots$ & ---- & 50 \\
\hline 6 & $\begin{array}{l}---* \\
----- \\
----- \\
----- \\
----- \\
----- \\
----- \\
----- \\
----- \\
-----\end{array}$ & $\begin{array}{l}* \\
* \\
-* \\
-* \\
--* \\
----- \\
----- \\
----- \\
-----\end{array}$ & $\begin{array}{l}* \\
* \\
-* \\
--1--\end{array}$ & ---- & ---- & ---- & 90 \\
\hline
\end{tabular}




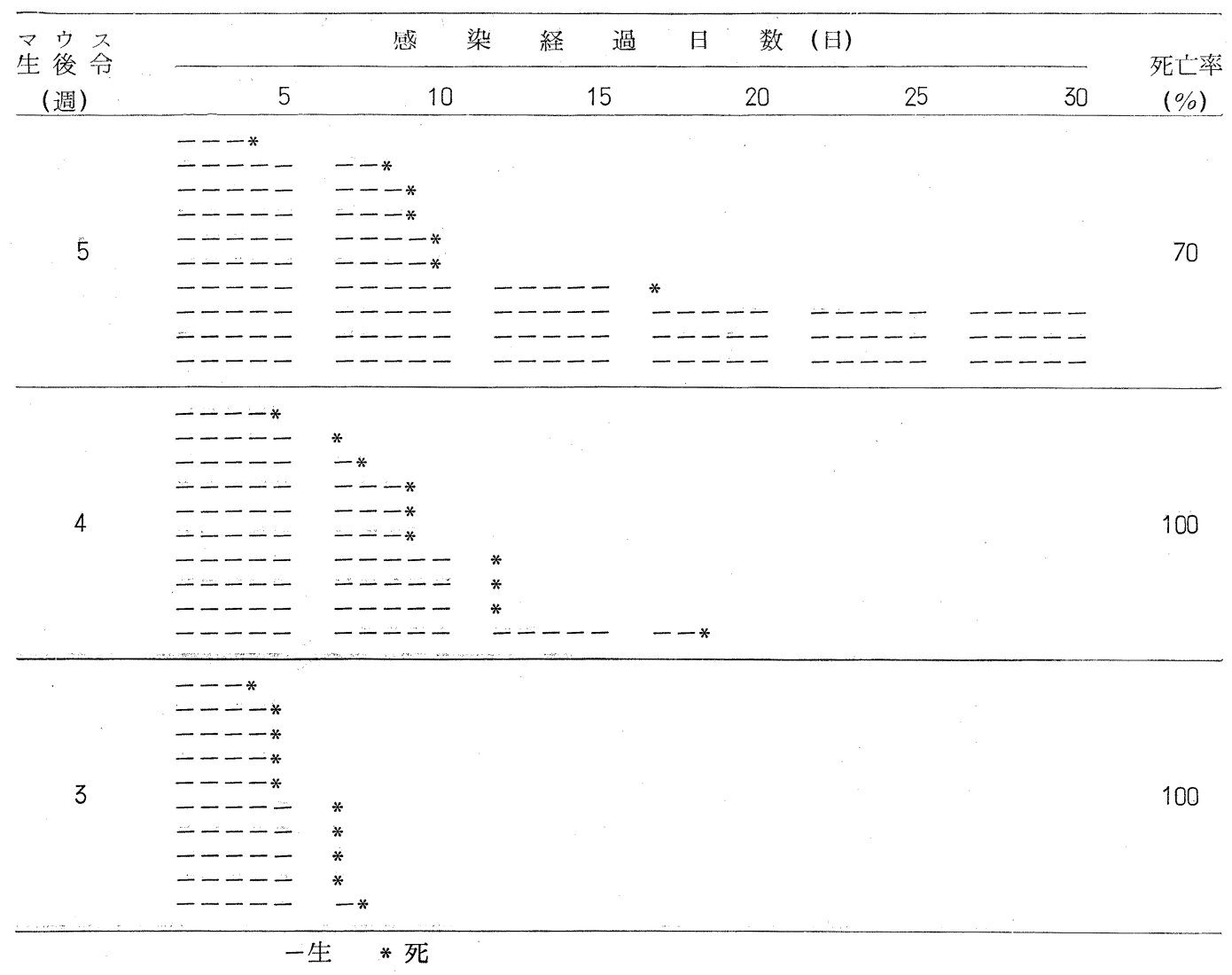

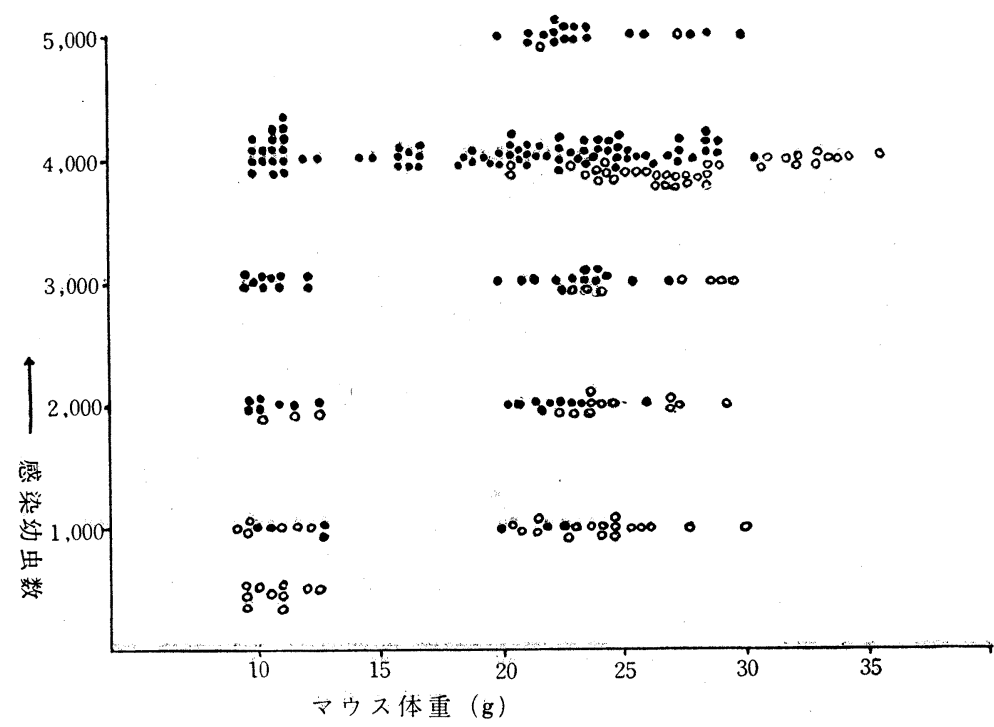

図 4 マウスの体重（生後日数）と感染幼虫の数によるマウスの死 亡状況の変化

$\bigcirc$ 生存 * 死亡 (但し30日観察)
8 日培養の幼虫を夫々 $4,000,3,000,2,000,1,000$ 隻宛各群のマウスに感染させ た場合の死亡率は夫々 $100 \%$ ， 100\%，70\%，40\%であっった。 4 週間培養の 幻虫 4,000 隻, 3,000 隻，2,000隻，1,000 隻 を夫々マウス（1 群10匹）に 感染させた場合の死亡率は各 $100 \%, 70 \% ， 40 \% ， 20 \%$ て 南った。.又 5 週間培養の幼虫 を用いて同様にマウスに感染 させた場 合の死亡率は夫々 $100 \%, 90 \%, 70 \%, 20 \%$ で あった。之等の死亡率の結果 について検討したところ8 日 培養の幼虫を用いて感染を行 った場合のマウスの死亡率と 
4〜 5 週間培養の幼出を用いて感染を行ったた拐 合のマウスの死亡率との間には $5 \%$ の危険率で 有意の差は認められなかっった（表 5 ).

表 5 名種培養幼虫の感染による死亡率 の比較

幼虫: $28^{\circ} \mathrm{C}, 8$ 日培養 マウス: 生後了週ddN系雄マウス ( 1 群10匹)

\begin{tabular}{|c|c|c|c|c|}
\hline \multicolumn{2}{|c|}{ 幼虫培養日数 } & 8 日 & 4 週 & 5 週 \\
\hline マウス & 平均体重 & $10.8 \mathrm{~g}$ & $12.7 \mathrm{~g}$ & $12.2 \mathrm{~g}$ \\
\hline \multirow{4}{*}{$\begin{array}{l}\text { 幼 } \\
\text { 虫 } \\
\text { 感 } \\
\text { 染 } \\
\text { 数 }\end{array}$} & 1,000 & $40 \%$ & $20 \%$ & $20 \%$ \\
\hline & 2,000 & $70 \%$ & $40 \%$ & $70 \%$ \\
\hline & 3,000 & $100 \%$ & $70 \%$ & $90 \%$ \\
\hline & 4,000 & $100 \%$ & $100 \%$ & $100 \%$ \\
\hline
\end{tabular}

\section{考察}

マウスに鈎虫幼虫を経口感染させて，死亡状 沉を観察した報告は Kerr ${ }^{1)}$ の実験 報告中にわ づかに見られる程度でその実験に於てもマウス の生後日数（体重）及び奻虫の培養日数等の記 載がない。三橋等 22 は実験的チフス症の研究に 於てゲルトネル菌の感染に伴う宿主（マウス） の病的変化として体重の変化が著明に認められ ると述へている，今回著者等は種々の生後日数 の ddN 系雄マウスについて感染奵虫数，マウ ス体重の変化並びに死亡率等の関係について検 討を試み同一幼虫感染数に対し幼若マウスは老 マウスより死亡率が高く，又感染死を免れたマ ウスの体重の回復は比較的速いことを知った。

又同様マウスについて新鮮なフィラリア型幼 虫と長期培養の㭃虫による死亡率との比較を 8 日培養幼虫と4～5週間培養の幼虫について行·っ たが著明な感染能の差異は認められなかっった。 白井 ${ }^{3)}$ は大鈎虫幼虫を犬に経口感染させた実験 に於て幼若フィラリア型幼虫に比べ培養 2 ケ月 の幼虫は成虫になる率が稍劣ると述へている。

一方稲留 ${ }^{4)}$ は犬に笹田 ${ }^{5}$ はマウスに経皮感染実 験を行って幼虫の培養日数と感染能について培 養 7 日万至 10 日位が最も感染能は強く, 日を追
って減弱し，培養1ケ月，2 ケ月のものには腎 染能の低下を著明に認貌たと述へている。等 の報告から拗虫の感染能に関しては経口，経皮 の雨者によって異った見方をするのが妥当と考 えられた。この点に関しマウスについて後日経 皮感染実験により結論を得たいと考えている。

\section{結 論}

（1） $28^{\circ} \mathrm{C} 8$ 日培養の犬鈎虫幼虫を用い，生後 $3,4,5,6,7,8,9,10$ 及び16週の 各 $\mathrm{dd} \mathrm{N}$ 系マウスに種々の数の幼虫を以て経 口感染を行い体重の変化，死亡状況等を観察 したところ，幼若マウスは老マウスに比べ感 染死亡率が高かっった。

（2）生後 3 週マウス，5週マウス，8週マウス のLD50は夫及約1 200隻，1,600隻及び3,200 隻で感染耐過マウスの体重回復は生後日数の 若いもの程速かった。

(3) 経口感染の場合, 幼虫の培養日数之感染能 との関係について，4～5週の長期培養幼虫は 8 日培盖の新鮮フィラリア型㭃虫に比心感染 能について著明な差異は認められなかった。

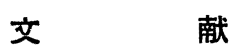

1) Kerr, K. B. : Studies on acquired immunity to the dog hookworm, Ancylostoma $x$ xcaninum. Am. J. Hyg., 24 : 381-406, 1936.

2）三橋進, 橋本一, 本多忠衛, 柿沼義包: 実験的于 フス症の研究（特にマウス刘腸炎菌の組合せにつ いて) $\mathrm{Xa}$ ：強毒菌辱染時のマウス体重の変化につ いて, 日本細菌学雑誌，15:661-667, 1960.

3）白井光次 : 十二指腸虫の経口感染に関する実験的 研究, 特に宿主体内移行に就て, 日本病理学会会 誌，第16年：223-233，1926.

4) 稲留藤次郎: 経皮感染後筋肉内に移行せる十二指 腸虫仔虫に就て, 慶応医学, 12:419-451 1932.

5）笹田丁二：人十二指腸虫の異宿主動物（白鼠）体 内に於ける発育、慶応医学, 16:67-80, 1936 . 


\section{STUDIES ON HOOKWORM IMMUNITY (ANCYLOSTOM ACANINUM)}

2) ON SUSGEPTIBILITY OF MIGE AGAINST LARVAE AND INFECTIVITY OF LARVAE TO MIGE

Toshisada Sawada, Megumi Kono

Department of Hygiene, School of Midicine, Gunma Uuiversity

The susceptibility of ddN strain mice against Hookworm was studied by observing the change of the body weight and the mortality of mice infected with larvae of Ancylostoma caninum orally and the following results were obtained:

1) Reduction of the body weight of mice were observed as a results of infection of larvae in a few days, and the young mice showed a higher mortality than the old.

2) Lethal doses of 50 per cent to mice varied according to the age of the mouse as follows: they were in 3 weeks old mice, about 1,200 larvae in 5 weeks old mice, about 1,600 larvae and in 8 weeks old mice about 3,200 larvee. The recovering of the body weight of survived mice was rapid in young mice.

3) The remarkable reduction of the infection rate of larvae was not found by the preservation of larvee for 4 to 5 weeks at $28^{\circ} \mathrm{C}$.

\section{鈎虫の感染と免疫}

第 3 報 マウスに犬鈎虫幼虫を経口感染させた場合の幼

虫の体内分布について

$$
\text { 河野恵・沢田利貞 }
$$

群馬大学医学部衛生学教室

緒

非固有宿主に於ける鈎虫幼虫の感染実験には 人鈎虫を大に感染させた三輪1，犬鈎虫をラッ テに感染させた，笹田 ${ }^{2}$, 明田川 ${ }^{3)}$, 松崎 ${ }^{4}$ 並び に犬鈎虫を家鬼に感染させた明田川 ${ }^{3}$ 等の報告 があるが何れの実験に於ても幼虫の体内移行は 認められている。

又余語5) は，マウスについて始めて実験を行 っているが㓜虫の体内移行についての詳細な記 載はない。著者はマウスを用いて, 経口感染の 場合の幼虫の体内移行について基礎実験を行っ た。

\section{実験材料並びに方法}

幼虫は鈎虫感染犬より採った鈎虫畉含有便を瓦培養 して得た 8 日目のフィラリア型幼虫を用い, 実験動物 は生後 5 週の ddN 系マウスを原則として使用した。 前実験によって生後 5 週のマウスは 2,000 隻の幼虫 を感染させた場合約10日以内には死亡しないことがわ かっているので幼虫感染数は原則として2,000 隻とし た・感染方法は前報と同様経口感染によった・

体内からの幼虫の分離並びに計数の方法はマウスを 固定台に固定し, 靧部を切断して殺し, 次に解剖して 各藏器を分離して少量の水を入れたシャーレに入れ䤲 で可及的に細切し円筒（直径 $4 \mathrm{~cm}$ 深さ $13.5 \mathrm{~cm}$ ）に桐垂

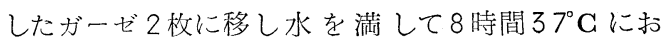

